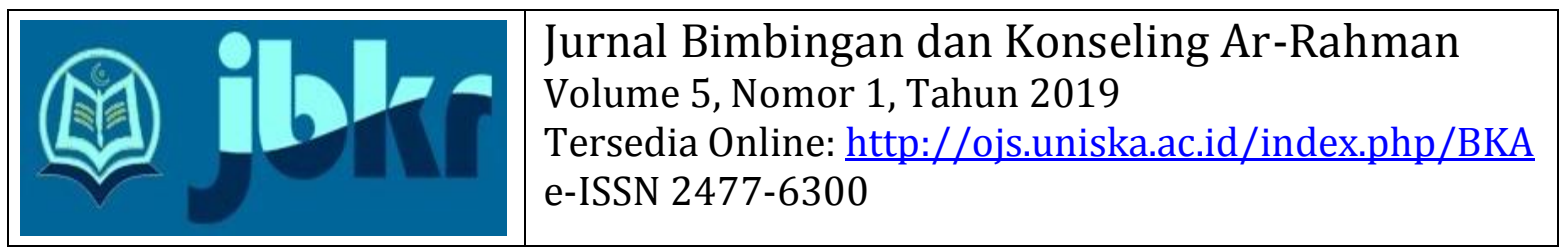

\title{
STUDI KOMPARATIF: PERBEDAAN STATUS IDENTITAS DIRI REMAJA DITINJAU DARI POLA ASUH ORANGTUA DI UNIVERSITAS X DI JAKARTA
}

\author{
Yeni Anna Appulembang ${ }^{1}$, Agustina $^{2}$ \\ ${ }^{1}$ Fakultas Kedokteran-Prodi Psikologi Universitas Sriwijaya \\ ${ }^{2}$ Fakultas Psikologi Universitas Tarumanagara \\ ${ }^{1}$ E-mail: yenianna@fk.unsri.ac.id/082260596377 \\ ${ }^{2}$ E-mail: agustina@fpsi.untar.ac.id/08170705303
}

\begin{abstract}
ABSTRAK
Penelitian ini bertujuan untuk mengetahui perbedaan status identitas diri remaja ditinjau dari pola asuh. Subyek yang digunakan adalah remaja yang kuliah di Universitas X di Jakarta dipilih dengan menggunakan Purposive Sampling. Peneliti menggunakan pendekatan kuantitatif komparatif dengan melakukan uji perbedaan. Alat ukur yang digunakan ada dua yaitu pola asuh dan Identitas diri. Berdasarkan hasil pengujian reliabilitas dan validitas maka diperoleh nilai Alpha Cronbach pada pola asuh ayah dimensi acceptance sebesar 0.940 dan pola asuh Ibu sebesar 0.930 dan dimensi demandingness pada pola asuh ayah sebesar 0.825 dan pola asuh ibu sebesar 0.874 . Sedangkan pada status identitas identity diffusion sebesar 0.567; identity foreclosure sebesar 0.652; identity moratorium sebesar 0.309 dan identity achievement sebesar 0.674. Analisis data pada penelitian ini menggunakan uji perbedaan Kruskal Wallis dan hasilnya menunjukkan bahwa tidak terdapat perbedaan status identity diffusion, identity moratorium, identity achievement, namun terdapat perbedaan status identity foreclosure ditinjau pola asuh Ayah. Pada pola asuh ibu, ditemukan tidak terdapat perbedaan pada identity diffusion dan identity achievement namun terdapat perbedaan status identity foreclosure dan identity moratorium. Adapun rekomendasi dari penelitian ini adalah orangtua perlu mendampingi anak dalam tahap perkembangannya sehingga anak dapat menentukan status identitasnya.
\end{abstract}

Kata Kunci: Status Identitas Diri, Pola Asuh orangtua

\begin{abstract}
The aim of this research to determine differences self identity with parenting style. Subject in this research used adolescences in University $X$ Jakarta using purposive sampling. The study was a quantitative research with design was comparative study. The instrument used was a questionnaire such as Parenting style and Self Identity. The reliability and validity test used Alpha Cronbach and the values was 0.940 for acceptance of father's parenting style and 0.930 of mother's parenting style. Otherwhile, 0.825 for demandingness of father's parenting style and 0.874 of mother's parenting style. The validity dan reliability of self identity statuse was 0.567 for identity diffusion; identity foreclosure was 0.652; identity moratorium was 0.309 and identity achievement was 0.674. The analysis data used Kruskal Wallis and the result found that there is no difference between self identity in adolescent dimension identity diffusion, moratorium and identity achievement but there is difference between self identity foreclosure with the father's parenting style. Otherwhile, there is no difference between identity diffusion and identity achievement but there is difference between identity foreclosure and identity moratorium of mother's parenting style. Recommend of this research to the parents can be monitor the development their children to found their identity statuse.
\end{abstract}

Keywords: Self identity; parenting style

Dipublikasikan Oleh :

UPT Publikasi dan Pengelolaan Jurnal

Universitas Islam Kalimantan Muhammad Arsyad Al-Banjari Banjarmasin 


\section{PENDAHULUAN}

Masa remaja merupakan masa peralihan dari masa anak-anak menuju masa dewasa yang terjadi dalam rentang usia 12-20 tahun (Papalia \& Martorell, 2014). Pada usia ini, remaja seolah lepas dari peran orangtua dan lebih mandiri dalam pengambilan keputusan. Remaja biasanya memiliki keinginan yang kuat untuk dapat mandiri dan bertanggung jawab terhadap perilaku sendiri (Santrock, 2011). Selain itu, remaja cenderung menyesuaikan diri dengan kelompok pergaulannya apabila tidak memiliki keyakinan terhadap identitas sosialnya (Prienstein dalam Santrock, 2011). Pembentukan identitas pada masa remaja merupakan masalah yang penting. Para remaja biasanya dituntut untuk dapat mengatasi krisis identitas mereka secara memuaskan (Indonesian Psychological Journal dalam Afrilyanti1, Herlina2, 2015). Menurut Papalia dan Martorell (2014), individu yang tidak mampu mengembangkan identitas dirinya dan ketaatan (fidelity) maka akan memiliki kepekaan diri yang tidak stabil, menjadi insecure, dan gagal dalam membuat rencana untuk diri mereka sendiri dan masa depannya.

Identitas diri adalah perasaan-perasaan yang berasal dari apa yang individu pikirkan mengenai dirinya. Individu yang sedang membentuk identitas diri adalah individu yang ingin menentukan siapakah dan apakah dirinya pada saat ini serta siapakah atau apakah yang individu inginkan dimasa yang akan datang (Gardner dalam Afrilyanti1, Herlina2, 2015).

Status identitas mengacu kepada proses perkembangan identitas sebagai karakteristik dari remaja (Steinberg, 2017). Status identitas diri terdiri dari identity diffusion, foreclosure, moratorium, dan identity achievement. Individu yang berada pada identitas diri diffusion biasanya tidak mengalami krisis dan tidak membuat komitmen. Individu pada kategori ini tampak tidak bahagia dan sering menyendiri. Selain itu, Individu pada kategori ini juga tidak dapat memutuskan mengenai suatu pekerjaan dan tidak terlalu khawatir terkait pekerjaan meskipun mereka mampu untuk menyebutkan pekerjaan yang diminatinya (Papalia \& Martorell, 2014).

Pada status identitas foreclosure, biasanya individu dapat membuat komitmen tanpa melalui krisis. Mereka membuat komitmen, sesuai dengan rencana yang telah diterima dari orang lain dan bukan dari hasil dari eksplorasi dari pilihan yang ada. Individu pada kategori ini akan sulit untuk mengkomunikasikan mengenai hal yang diinginkan kepada orangtua mereka. Biasanya mereka akan menjadi apa yang telah disiapkan dan ditentukan untuknya sebagai anak (Papalia \& Martorell, 2014).

Pada status identitas moratorium, biasanya mereka menghadapi krisis namun belum membuat komitmen. Namun, mereka mungkin akhirnya akan keluar dari krisis dengan kemampuan membuat komitmen dan mencapai identitasnya. Individu yang berada pada identity achievement, mengalami krisis yang mengarah pada komitmen. Jadi, mereka telah memecahkan krisis identitasnya. Individu pada kategori ini, tampak aktif berjuang untuk membuat komitmen. Meskipun harapan orangtua masih penting bagi mereka, namun mereka akan tetap berusaha untuk berkompromi dengan orangtua, harapan masyarakat, dan kemampuannya sendiri (Papalia \& Martorell, 2014).

Beberapa penelitian mengenai status identitas menemukan bahwa individu yang mendapatkan skor yang tinggi pada identitas achievement akan lebih tinggi pada pengukuran achievement motivasi, penalaran moral, hubungan yang intim dengan teman sebaya, dan kematangan dalam karir. Individu yang mendapatkan skor menengah pada moratorium akan mendapatkan skor yang tinggi pada pengukuran kecemasan, dimana individu menunjukkan konflik yang berkaitan dengan otoritas, kaku, dan paling rendah dalam authoritarian. Individu yang termasuk dalam forclosure status menunjukkan lebih authoritarian dan lebih mudah curiga serta membutuhkan penerimaan sosial, rendah dalam level autonomy dan sangat dekat dengan orangtua. Individu dengan identity diffusion akan tinggi pada level psychological, perilaku dan masalah interpersonal yang ditunjukkan dengan perilaku menarik diri dari lingkungan sosial, anti sosial dan tingkat keintiman yang rendah dengan teman-teman sebaya (Steinberg, 2017). Penelitian lain yang dilakukan oleh Agustina dan Satiadarma (2017) menunjukkan bahwa status identitas berperan signifikan terhadap pengambilan keputusan pemilihan jurusan.

Dalam pengembangan identitas anak serta perkembangan remaja, peran orangtua sangat penting (Des, Malaisiens, Les, Yunus, dan Jusoff, 2010). King (2011) menambakan bahwa orangtua memiliki peran penting pada perkembangan anak. Santrock menemukan bahwa pola asuh orangtua memberikan pengaruh terhadap identitas achievement (identity achievement) pada remaja. Berdasarkan beberapa literatur, pola asuh yang orangtua terapkan dapat mengajarkan anak bagaimana untuk berperilaku sesuai dengan etika dan nilai-nilai serta bagaimana mengambil keputusan. Selain itu, beberapa studi menyebutkan bahwa pola asuh sebagai dasar pembentukan identitas (Laboviti, 2015). Menurut Parke dan Buriel (dalam Santrock, 2011), orang tua memiliki peran dalam mengatur kesempatan yang ada bagi remaja yaitu dengan mengawasi hubungan remaja dan berperan sebagai inisiator sosial. Salah satu aspek yang berperan penting dalam perkembangan anak adalah pola asuh yang diterapkan oleh orangtua kepada anak dan akan membentuk 
perilaku anak ketika tumbuh menjadi remaja. Pola asuh orangtua adalah suatu cara bagaimana orangtua mengasuh dan mendidik anak (Santrock, 2009 ).

Menurut Baumrind (1991) terdapat dua dimensi mayor pola pengasuhan orang tua, yaitu demandingness dan responsiveness. Dimensi responsiveness/acceptance mencakup aspek penerimaan (nurturance) dan komunikasi antara orang tua dan anak (parent-child communication). Dimensi ini memperlihatkan seberapa besar orang tua bersikap mendukung dan peka terhadap kebutuhan anak serta kesediaan untuk memberikan kasih sayang dan pujian ketika mereka berhasil mencapai harapannya. Orang tua yang accepting/responsive sering memberikan senyuman, pujian, dan dorongan kepada anaknya. Namun mereka juga dapat bersikap kritis jika anak berperilaku tidak baik. Sebaliknya, orang tua yang kurang accepting/responsive sering meremehkan, mengkritik, menghukum atau tidak mempedulikan anak serta jarang mengkomunikasikan apa yang mereka sukai dan inginkan pada anak. Aspek-aspek yang tercakup di dalam dimensi demandingness/control adalah parental control dan maturity demand. Dimensi ini mengukur seberapa banyak aturan dan kontrol yang ditetapkan orang tua terhadap anaknya. Orang tua yang controlling/demanding membuat peraturan-peraturan dan menuntut anak-anaknya untuk mematuhi aturan tersebut. Mereka memonitor dari dekat kegiatankegiatan anak untuk meyakinkan bahwa peraturanperaturan tersebut dipatuhi. Sebaliknya dengan orang tua yang kurang controlling/undemanding jauh lebih lunak, mereka hanya memberikan sedikit tuntutan dan memberikan kebebasan yang seluas-luasnya pada anak untuk melakukan segala keinginannya dan membuat keputusan sendiri tentang kegiatan mereka.

Baumrind menggunakan dua dimensi demandingness dan responsiveness untuk mengembangkan empat tipe pola asuh yang menggambarkan bagaimana orangtua dapat mengkombinasikan pengasuhan anak dan batas aturan dalam keluarga. Empat tipe pola asuh itu adalah authoritative, authoritarian, neglectful, dan indulgent/permissive. Pola asuh authoritative merupakan pola asuh yang menekankan pada usaha mendorong anak untuk dapat menjadi mandiri, namun tetap memberikan batasan dan pengawasan. Pola asuh authoritarian merupakan pola asuh yang menekankan pada tindakan menghukum dan menetapkan banyak batasan, dimana orang tua mengharuskan anak mengikuti perintah orang tua dan menghargai pekerjaan dan usaha. Pola asuh neglectful merupakan pola asuh dimana orang tua sama sekali tidak melibatkan diri dalam kehidupan anak-anaknya. Pola asuh indulgent/permissive merupakan pola asuh yang menekankan pada pemberian kebebasan pada anak atas apapun kemauan ataupun pilihan mereka ( Santrock, 2009). Penelitian yang dilakukan oleh (Afrilyanti1, Herlina2, 2015) menunjukkan bahwa terdapat hubungan antara pola asuh dengan identitas diri remaja. Pembentukan identitas diri pada remaja dipengaruhi pola asuh yang diberikan oleh orangtua. Hasil penelitian yang dilakukan oleh Laboviti, 2015 menunjukkan bahwa tidak terdapat hubungan antara pola asuh authoritarian dengan status identitas serta tidak menunjukkan hubungan yang signifikan antara pola asuh authoritative dengan identitas moratorium.

Berdasarkan penjelasan diatas maka rumusan masalah pada penelitian ini adalah apakah terdapat perbedaan status identitas pada remaja ditinjau dari pola asuh orang tua mereka.

Adapun tujuan penelitian ini untuk mengetahui perbedaan status identitas ditinjau dari dari pola asuh (authoritative, authoritarian, permissive, neglect).

\section{METODE}

Adapun hipotesis penelitian ini adalah terdapat perbedaan status identitas pada remaja ditinjau dari pola asuh orangtua. Subyek yang digunakan dalam penelitian ini adalah remaja yang kuliah di Universitas $\mathrm{X}$ di Jakarta yang dipilih dengan menggunakan Purposive Sampling. Jumlah subyek yang digunakan pada penelitian ini sebanyak 113 orang dengan rentang usia 17-21 tahun. Pada penelitian ini, peneliti menggunakan pendekatan kuantitatif komparatif dengan menggunakan uji perbedaan.

Adapun alat ukur yang digunakan ada dua yaitu pola asuh dan status identitas. Pada alat ukur pola asuh, yang menggunakan alat ukur yang telah dikembangkan oleh Chandra dan Suyasa (2006) dengan berlandaskan teori Baumrind (1991). Alat ukur pola asuh orangtua terdiri atas dua jenis yaitu pola asuh ibu dan pola asuh ayah. Masing-masing terdiri atas dimensi yaitu acceptance/responsiveness dan demandingness/control. Dari dua dimensi ini yang akan membentuk empat (4) jenis pola asuh yaitu authoritarian, authoritative, permissive, dan neglect. Alat ukur ini memiliki 34 butir pernyataan dengan skala Likert yang dibagi menjadi empat (4) pilihan, yaitu $1=\mathrm{STS}, 2=\mathrm{TS}, 3=\mathrm{S}$, dan $4=\mathrm{SS}$.

Alat ukur kedua adalah status identitas dengan menggunakan Extended Version of The Objective Measure of Ego-Identity Status (Bennion \& Adams, 1986). Alat ukur ini memiliki empat (4) dimensi yaitu identity diffusion, foreclosure, moratorium, dan identity achievement yang terdiri dari 26 butir pernyataan menggunakan skala Likert yang dibagi menjadi Lima (5) pilhan jawaban yaitu $1=\mathrm{STS}, 2=$ $\mathrm{TS}, 3=\mathrm{RR}, 4=\mathrm{S}$ dan $5=\mathrm{SS}$.

Pengujian reliabilitas dan validitas pada penelitian ini menggunakan Internal Consistency Alpha Cronbach. Pada alat ukur pola asuh ayah 
Yeni Anna Appulembang, Agustina Jurnal Bimbingan dan Konseling Ar-Rahman

Volume 5, Nomor 1, Tahun 2019

e-ISSN 2477-6300

dimensi acceptance/responsiveness memiliki Internal Consistency Alpha Cronbach sebesar 0,940 dan dimensi demandingness/control sebesar 0,825. Sedangkan pola asuh Ibu, pada dimensi acceptance/responsiveness memiliki Internal Consistency Alpha Cronbach sebesar 0.930 dan dimensi demandingness/control sebesar 0.874. Untuk lebih ringkas dapat dilihat pada tabel 1 .
Pada Pengujian reliabilitas dan validitas alat ukur identity status, maka diperoleh Internal Consisncy Alpha Cronbach Pada dimensi identity diffusion, sebesar 0.567; identity foreclosure sebesar 0.652; identity moratorium sebesar 0.309 dan identity achievement, sebesar 0.674. Untuk lebih ringkas dapat dilihat pada tabel 1 dan 2 .

Tabel 1. Uji Reliabilitas Alpa Cronbach alat ukur Pola Asuh Orangtua

\begin{tabular}{lll}
\hline Pola Asuh & Dimensi & Alpa Cronbach \\
\hline Ayah & Acceptance/responsiveness & 0.940 \\
& Demandingness/control & 0.825 \\
\hline Ibu & Acceptance/responsiveness & 0.930 \\
& Demandingness/control & 0.874 \\
\hline
\end{tabular}

Tabel 2. Uji Reliabilitas Alpa Cronbach Alat Ukur Identity Status

\begin{tabular}{lc}
\hline Dimensi & Alpa Cronbach \\
\hline Identity diffusion & 0.567 \\
Foreclosure & 0.652 \\
Moratorium & 0.309 \\
Identity achievement & 0.674 \\
\hline
\end{tabular}

\section{Gambaran Data}

Gambaran data pada pola asuh ayah, sebagai berikut: terdapat 81 subyek ( $71.7 \%$ ) yang memiliki pada pola asuh authoritative, authoritarian sebanyak 12 subyek (10.6\%), permissive sebanyak 11 subyek $(9.7 \%)$ dan neglect sebanyak 9 subyek $(8.0 \%)$. Sedangkan pada pola asuh ibu, maka diperoleh gambaran sebagai berikut: terdapat 93 subyek ( $82.3 \%$ ) yang memiliki pola asuh authoritative, authoritarian sebanyak 5 subyek (4.4\%), permissive sebanyak 14 orang (12.4\%) dan neglect sebanyak 1 subyek $(0.9 \%)$. Untuk lebih ringkas dapat dilihat pada tabel 3 .

Tabel 3. Gambaran Pola Asuh Orangtua

\begin{tabular}{|c|c|c|c|}
\hline Pola Asuh & Tipe Pola Asuh & Frekuensi & Presentase \\
\hline Ayah & $\begin{array}{l}\text { Authoritative } \\
\text { Authoritarian } \\
\text { Permissive } \\
\text { Neglectful }\end{array}$ & $\begin{array}{c}81 \\
12 \\
11 \\
9\end{array}$ & $\begin{array}{c}71.7 \\
10.6 \\
9.7 \\
8.0\end{array}$ \\
\hline Ibu & $\begin{array}{l}\text { Authoritative } \\
\text { Authoritarian } \\
\text { Permissive } \\
\text { Neglectful }\end{array}$ & $\begin{array}{c}93 \\
5 \\
14 \\
1\end{array}$ & $\begin{array}{c}82.3 \\
4.4 \\
12.4 \\
0.9\end{array}$ \\
\hline
\end{tabular}

\section{HASIL DAN PEMBAHASAN}

Berdasarkan analisis data dengan menggunakan Kruskal Wallis untuk menguji perbedaan status identitas dengan menggunakan empat (4) dimensi yaitu Identity foreclosure, identity achievement, identity moratorium dan identity diffusion ditinjau dari pola asuh ayah dengan menggunakan empat jenis pola asuh (authoritative, authoritarian, permissive, dan neglect maka diperoleh hasil sebagai berikut pada tabel 4 dan 5:

Dipublikasikan Oleh :

UPT Publikasi dan Pengelolaan Jurnal

Universitas Islam Kalimantan Muhammad Arsyad Al-Banjari Banjarmasin 
Yeni Anna Appulembang, Agustina Jurnal Bimbingan dan Konseling Ar-Rahman

Volume 5, Nomor 1, Tahun 2019

e-ISSN 2477-6300

Tabel 4. Perbedaan Status Identitas di Tinjau dari Pola Asuh Orangtua

\begin{tabular}{ccccc}
\hline Status Identitas & $\begin{array}{c}\text { Pola Asuh } \\
\text { Ayah }\end{array}$ & Mean Rank & $\boldsymbol{p}$ & Keputusan \\
& Authoritative & 102.19 & & Ada Perbedaan \\
& Authoritarian & 79.67 & 0.003 & \\
Identity Foreclosure & Permissive & 79.09 & & \\
& Neglectful & 67.39 & & \\
\hline
\end{tabular}

Tabel 4. Perbedaan Status Identitas di Tinjau dari Pola Asuh Orangtua

\begin{tabular}{|c|c|c|c|c|}
\hline Status Identitas & Pola Asuh Ayah & Mean Rank & $p$ & Keputusan \\
\hline \multirow{4}{*}{ Identity Achievement } & Authoritative & 97.28 & \multirow{4}{*}{0.097} & \multirow{4}{*}{ Tidak Ada Perbedaan } \\
\hline & Authoritarian & 72.75 & & \\
\hline & Permissive & 82.05 & & \\
\hline & Neglectful & 80.33 & & \\
\hline \multirow{4}{*}{ Identity Moratorium } & Authoritative & 78.60 & \multirow{4}{*}{0.08} & \multirow{4}{*}{ Tidak Ada Perbedaan } \\
\hline & Authoritarian & 105.38 & & \\
\hline & Permissive & 95.68 & & \\
\hline & Neglectful & 88.11 & & \\
\hline \multirow{4}{*}{ Identity Diffusion } & Authoritative & 93.02 & \multirow{4}{*}{0.06} & \multirow{4}{*}{ Tidak Ada Perbedaan } \\
\hline & Authoritarian & 98.33 & & \\
\hline & Permissive & 68.68 & & \\
\hline & Neglectful & 85.11 & & \\
\hline
\end{tabular}

Tabel 5. Perbedaan Status Identitas di Tinjau dari Pola Asuh Orangtua

\begin{tabular}{|c|c|c|c|c|}
\hline Status Identitas & Pola Asuh Ibu & Mean Rank & $p$ & Keputusan \\
\hline Identity Foreclosure & $\begin{array}{c}\text { Authoritative } \\
\text { Authoritarian } \\
\text { Permissive } \\
\text { Neglectful }\end{array}$ & $\begin{array}{l}97.63 \\
65.67 \\
67.42 \\
11.00\end{array}$ & 0.000 & Ada Perbedaan \\
\hline Identity Achievement & $\begin{array}{c}\text { Authoritative } \\
\text { Authoritarian } \\
\text { Permissive } \\
\text { Neglectful }\end{array}$ & $\begin{array}{l}88.35 \\
84.67 \\
85.79 \\
85.00\end{array}$ & 0.988 & Tidak Ada Perbedaan \\
\hline Identity Moratorium & $\begin{array}{c}\text { Authoritative } \\
\text { Authoritarian } \\
\text { Permissive } \\
\text { Neglectful }\end{array}$ & $\begin{array}{c}86.38 \\
105.27 \\
92.16 \\
19.50\end{array}$ & 0.019 & Ada Perbedaan \\
\hline Identity Diffusion & $\begin{array}{c}\text { Authoritative } \\
\text { Authoritarian } \\
\text { Permissive } \\
\text { Neglectful }\end{array}$ & $\begin{array}{l}89.89 \\
99.47 \\
78.55 \\
38.00\end{array}$ & 0.094 & Tidak Ada Perbedaan \\
\hline
\end{tabular}

Berdasarkan hasil uji beda dengan menggunakan Kruskal Wallis pada identity foreclosure ditinjau dari pola asuh ayah maka diperoleh nilai $p=0.003<0.05$. Hal ini menunjukkan bahwa ada perbedaan identity foreclosure ditinjau dari pola asuh ayah. Sedangkan pada pola asuh ibu menunjukkan nilai $p=$ $0.000<0,05$. Hal ini menunjukkan bahwa ada perbedaan identity foreclosure ditinjau dari pola asuh ibu.

Dipublikasikan Oleh :

UPT Publikasi dan Pengelolaan Jurnal

Universitas Islam Kalimantan Muhammad Arsyad Al-Banjari Banjarmasin
Berdasarkan hasil uji beda dengan menggunakan Kruskal Wallis pada identity achievement ditinjau dari pola asuh ayah maka diperoleh nilai $p=0.097>0.05$. Hal ini menunjukkan bahwa tidak ada perbedaan identity achievement ditinjau dari pola asuh ayah. Sedangkan pada pola asuh ibu menunjukkan nilai $p=$ $0.988>0.05$. Hal ini menunjukkan bahwa tidak ada perbedaan identity achievement ditinjau dari pola asuh ibu. 
Berdasarkan hasil uji beda dengan menggunakan Kruskal Wallis pada identity moratorium ditinjau dari pola asuh ayah maka diperoleh nilai $p=0.08>0.05$. Hal ini menunjukkan bahwa tidak ada perbedaan identity moratorium ditinjau dari pola asuh ayah. Sedangkan pada pola asuh ibu menunjukkan nilai $p=$ $0.019<0.05$. Hal ini menunjukkan bahwa ada perbedaan identity moratorium ditinjau dari pola asuh ibu.

Berdasarkan hasil uji beda dengan menggunakan Kruskal Wallis pada identity diffusion ditinjau dari pola asuh ayah, maka diperoleh nilai $p=0.06>0.05$. Hal ini menunjukkan bahwa tidak ada perbedaan identity diffusion ditinjau dari pola asuh ayah. Sedangkan pada pola asuh ibu menunjukkan nilai $\mathrm{p}=$ $0.094>0.05$. Hal ini menunjukkan bahwa tidak ada perbedaan identity diffusion ditinjau dari pola asuh ibu.

Hasil analisis data menunjukkan bahwa tidak terdapat perbedaan status identitas identity diffusion, moratorium, dan identity achievement ditinjau dari pola asuh Ayah. Sedangkan pada pola asuh Ibu menunjukkan tidak terdapat perbedaan status identitas identity achievement dan identity diffusion pada remaja. Hasil ini didukung oleh penelitian Amelia (2013) mengenai "Asosiasi antara Gaya Pengasuhan dan Status Identitas" hasilnya menunjukkan bahwa gaya pengasuhan orangtua yang dipandang subjek menunjukkan kebebasan yang tidak sepenuhnya (otoriter-otoritatif). Hal tersebut mendukung subjek untuk tidak dapat sepenuhnya dalam bereksplorasi dan berkomitmen, sehingga identitas diri juga belum tercapai sepenuhnya berupa kombinasi achievementmoratorium dan achievement-moratorium-foreclosure. Hasil penelitian ini sejalan dengan penelitian yang diakukan (Aldhafri \& Al-Harthy, 2016) menunjukkan bahwa tidak terdapat pola asuh orangtua dengan level moratorium siswa. Penelitian yang dilakukan oleh Anindyajati (2013) menunjukkan bahwa terdapat hubungan yang signifikan antara status identitas dan gaya pengasuhan orangtua. Marcia (dalam Papalia \& Martorell, 2014) menyebutkan bahwa individu yang berada pada identity diffusion, mereka tidak mengalami krisis dan tidak membuat komitmen. Jadi mereka yang berada pada kategori ini tampak tidak memerlukan peran orang tua karena tidak membuat komitmen. Demikian juga pada individu yang berada pada status identitas moratorium, mereka menghadapi krisis namun belum membuat komitmen. Jadi mereka yang berada pada kategori ini juga tampak tidak memerlukan peran orang tua karena mereka belum membuat komitmen. Sedangkan pada individu yang berada pada identity achievement, mereka mengalami krisis yang mengarah pada komitmen. Jadi, mereka telah memecahkan krisis identitasnya dengan kemampuannya sendiri. Oleh karena itu, orang tua tampak tidak memegang peranan penting bagi mereka untuk membuat komitmen.

Berdasarkan hasil analisis data, diketahui pula bahwa terdapat perbedaan status identitas foreclosure ditinjau dari pola asuh Ayah dan Ibu pada remaja Individu yang berada pada foreclosure membuat komitmen tanpa melalui krisis. gaya pengasuhan otoritatif memberikan persentase lebih besar untuk pencapaian identitas yang koheren. Menurut Marcia (dalam Papalia \& Martorell, 2014) mereka membuat komitmen, bukan sebagai hasil dari mengekplorasi pilihan-pilihan yang ada, namun karena menerima rencana dari orang lain untuk hidup mereka. Dalam hal ini, rencana hidup mereka telah ditentukan oleh orang tua. Oleh sebab itu, pola asuh orang tua tampak memegang peranan terhadap hidup mereka.

Berdasarkan hasil penelitian yang dilakukan oleh Christinna, Nurmaguphita, dan Rahayu (2017) menunjukkan bahwa Orang tua yang otoriter, yang mengontrol perilaku anak tanpa memberikan kesempatan anak mengeluarkan pendapatnya, akan mendorong status identity foreclosure. Orang tua yang permisif yang tidak memberikan arahan yang cukup bagi anak dan benar-benar membiarkan anak mengambil keputusan sendiri akan mendorong status identity diffusion. Penelitian yang dilakukan oleh (Aldhafri \& Al-Harthy, 2016) menunjukkan bahwa siswa yang diasuh dengan authoritatif akan mengembangkan foreclosure academic identity. Biasanya siswa menunjukkan komitmen dalam mengerjakan tugas, namun sangat tergantung dengan oranglain. Orangtua sangat mengontrol segala sesuatu pada anak, tidak ada diskusi ataupun negosiasi.

\section{PENUTUP}

Hasil analisis data menunjukkan bahwa tidak terdapat perbedaan identity diffusion, moratorium, dan identity achievement dan terdapat perbedaan pada identity foreclosure ditinjau dari pola asuh Ayah Sedangkan pada pola asuh Ibu menunjukkan tidak terdapat perbedaan status identitas identity achievement dan identity diffusion dan terdapat perbedaan pada identity foreclosure dan identity moratorium ditinnjau dari pola asuh ibu. Penelitian ini juga telah melalui proses monitoring dan evaluasi DPPM Untar.

Dengan adanya hasil penelitian ini, maka dapat memperkaya literatur pada bidang psikologi psikologi perkembangan dan pendidikan. Selain itu, dengan adanya hasil penelitian ini maka dapat mengkaji lebih mendalam terkait identitas status dan pola asuh untuk melengkapi penelitian-penelitian terdahulu. Oleh karena itu, peneliti menyarankan pada peneliti selanjutnya yang ingin melakukan penelitian terkait dengan identitas status maka dapat mengaitkan dengan variabel yang lain serta mempertimbangkan jumlah 
responden sehingga hasil penelitian dapat digeneralisasikan.

Selain itu, peneliti juga menyarankan agar orangtua mendampingi anak dan mengarahkan anak ketika membuat suatu komitmen. Orangtua tidak memaksakan kehendak kepada anak, tetapi orangtua hanya menuntun dan membimbing anak sehingga dapat membuat suatu komitmen dan dapat menentukan identitas mereka.

\section{REFERENSI}

Afrilyanti, Herlina, \& HD, S.R. (2015). Hubungan Pola Asuh Orangtua dengan Status Identitas Diri Remaja, 2 ( 2).

Agustina \& Satiadarma, M. P. S. (2017). The Role of Identity Statuses on Freshman Student's Decision Making in Choosing Education Degree Program. The Asian Conference on Psychology and The Behavioral Sciences Proceedings.

Aldhafri, S \& Al-Harthy. (2016). Undergraduate Omani Students' Identity and Perceptions of Parenting Styles. Canadian Center of Science and Education, 8 (2) doi:10.5539/res.v8n2p114

Amelia, J. (2013). Asosiasi antara Gaya Pengasuhan dan Status ldentitas Diri Remaja Etuis Jawa (Skripsi) Fakultas Psikologi Universitas Surabaya, Laboratorium Psikologi Perkembangan.

Anindyajati, P. D (2013). Identitas Remaja Akhir: Hubungannya Dengan Gaya Pengasuhan Orangtua Dan Tingkat Kenakalan Remaja, 1 (2).

Baumrind, D. (1991). The influence of parenting style on adolescent competence and substance use. Journal of Early Adolescence, 11(1), 56-95.

Christinna, M., Nurmaguphita, D. \& Rahayu, P.P. (2017). Hubungan Pola Asuh Orangtua Dengan Identitas Diri Pada Remaja Di SMP Negeri 2 Tempel Yogyakarta (Thesis (Skripsi) Program Studi S1- Ilmu Keperawatan Fakultas Kesehatan Universitas 'Aisyiyah Yogyakarta ). Diakses dari: http://digilib.unisayogya.ac.id/2548/

Laboviti, B. (2015). Relations Between the Parenting Styles and Identity Status of Teenagers in Albanian Context. Journal of Educational and Social Research MCSER PublishingRome-Italy, 5 (1) doi: :10.5901/jesr.2015.v5n1p65

Papalia, D. E. \& Martorell, G. (2014). Experience human development. (12rd ed.). Ny: McGraw Hill.
Santrock, J. W. (2011). Adolescence. Boston, USA: McGraw Hill.

Santrock, J. W. (2009). Psikologi Pendidikan: Educational Pyschology (3th ed.). (Angelica, D) Salemba Humanika.

Steinberg, L. (2017). Adolescences (11th ed.). NY: McGraw Hill.

Yunus, F.W., \& Kamal, A.H ( 2010). Gender Differences on the Identity Status of the Malaysian Preparatory Students, 6 (2),145-151.

Dipublikasikan Oleh :

UPT Publikasi dan Pengelolaan Jurnal

Universitas Islam Kalimantan Muhammad Arsyad Al-Banjari Banjarmasin 